VOLUME XXVI - NUMBeR 3 - September 1967
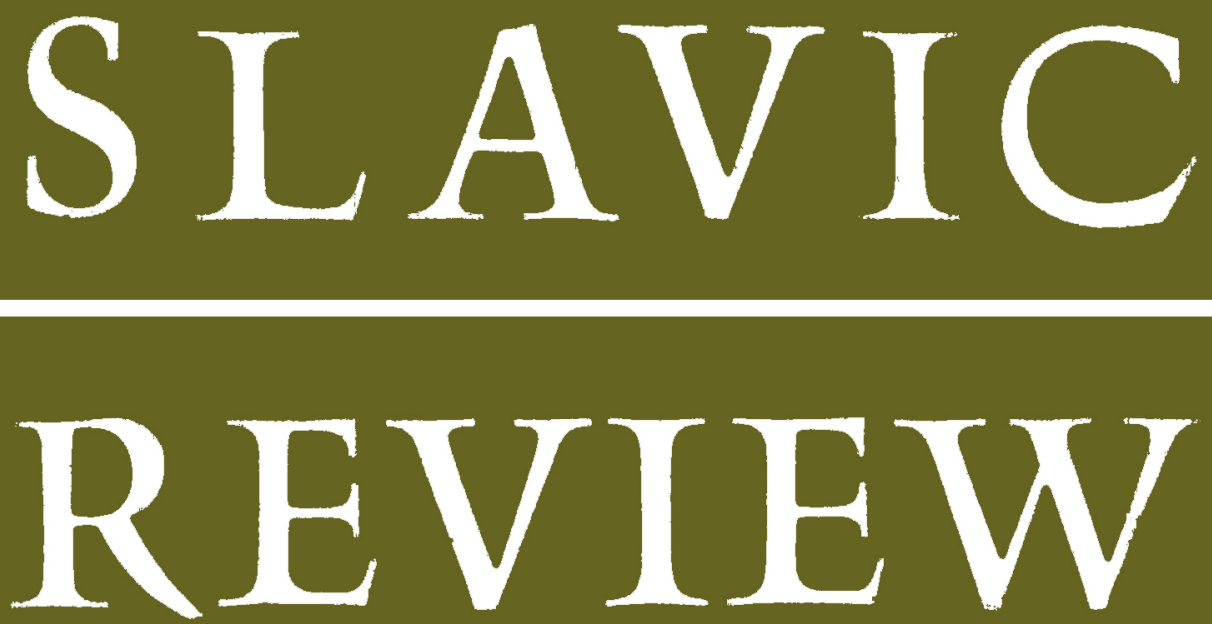

American Quarterly of Soviet and East European Studies 


\section{HONORARY EDITORS}

Harold H. Fisher Osgar Halegki Waglaw Lednicki Gerom T. Robinson Ernest J. Simmons S. Harrison Thomson George Vernadsky

\section{EDITORIAL ADVISORY COMMITTEE}

Frederick G. Barghoorn, Yale University - Abram Bergson, Harvard University - Cyril E. Black, Princelon University - Deming Brown, University of Michigan - Robert F. Byrnes, Indiana University - John S. Curtiss, Duke University - William B. Edgerton, Indiana University - Victor Erlich, Yale University - Merle Fainsod, Harvard University - Alexander Gerschenkron, Harvard University - Gregory Grossman, University of California - Chauncy D. Harris, University of Chicago - John N. Hazard, Columbia University - Alex Inkeles, Harvard University - Charles Jelavich, Indiana University - Anatole G. Mazour, Stanford University • Philip E. Mosely, Columbia University - Oliver H. Radkey, University of Texas - Alfred Senn, Universitv of Pennsylvania - Demitri B. Shimkin, University of Illinois - Gleb Struve, University of California - René Wellek, Yale University - Francis J. Whitfield, University of California

\section{EDITORIAL BOARD}

\section{Henry L. Roberts (History), Chairman}

William L. Blackwell (History), Loren R. Graham (History), Righard F. Gustafson (Literature), Grey Hodnett (Government), Rado L. Lencex (Linguistics), Robert A. Lewis (Geography), Robert A. Maguire (Literature), Harold Noah (Economics and Education), Marshall D. Shulman (Political Science)

\section{EDITORIAL STAFF}

managing editor, Louise E. Luke adjunct editor, Henry L. Roberts, Dartmouth College

assistant editor, Miriam Bergamini

STafF - Assistant, Uta-Renate Blumenthal

NEWS OF THE PROFESSION EDITOR, Frank Y. Gladney, University of Illinois

The Editors assume no responsibility for statements of fact or opinion made by contributors.

The Slavic Review (formerly The American Slavic and East European Review) is published quarterly, in March, June, September, and December, by the American Association for the Advancement of Slavic Studies, Inc., and is sent to all Association members. Members also receive an annual American Bibliography of Russian and East European Studies and a semiannual Newsletter. Applications for membership are accepted by the Secretary of the Association, Professor Ralph T. Fisher, 1207 West Oregon Street, University of Illinois, Urbana, Illinois 61801, from individuals professionally engaged in the field. Nonmembers also may place subscriptions with Professor Fisher. Subscriptions, without membership, are $\$ 12.00$ a year, foreign and domestic postage included. Single numbers are $\$ 3.25$.

Articles submitted and books for review, as well as all correspondence concerning editorial matters, should be addressed to Slavic Review, Columbia University, 622 West 113 Street, New York, New York 10025. All communications regarding membership and subscriptions should be sent to Professor Fisher in Urbana. Items for the "News of the Profession" section should also be addressed to the AAASS in Urbana.

Published for the American Association for the Advancement of Slavic Studies, Inc., at Mt. Royal and Guilford Avenues, Baltimore, Maryland 21202. Second-class postage paid at Baltimore, Maryland.

Copyright (C) 1967 by the American Association for the Advancement of Slavic Studies, Inc. 


\title{
SLAVIC REVIEW
}

AMERICAN QUARTERLY OF SOVIET AND EAST EUROPEAN STUDIES

Formerly: The American Slavic and East European Review

\author{
HENRY L. ROBERTS \\ Managing Editor until June 1967 \\ LOUISE E. LUKE \\ Managing Editor from July 1,1967
}

Columbia University

622 West I 13 Street, New York, N. Y. 10025

VOLUME XXVI • 1967

Copyright (c) 1967 by the American Association for the Advancement of Slavic Studies, Inc. 


\title{
CONTENTS OF VOLUME XXVI
}

\author{
Number 1, March 1967
}

\section{SYMPOSIUM}

John A. Armstrong: Comparative Politics and Communist Systems: Introductory Remarks $\ldots \ldots \ldots \ldots \ldots \ldots \ldots \ldots \ldots \ldots \ldots$

Alfred G. Meyer: The Comparative Study of Communist Political Systems .............................. 3

John H. Kautsky: Communism and the Comparative Study of Devel-

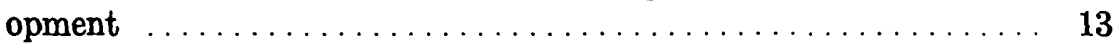

Dan N. Jacobs: Area Studies and Communist Systems .......... 18

Robert S. Sharlet: Systematic Political Science and Communist Systems ................................ 22

John A. Armstrong: Conclusion $\ldots \ldots \ldots \ldots \ldots \ldots \ldots \ldots \ldots, 27$

ARTICLES

Murray Yanowitch: Alienation and the Young Marx in Soviet

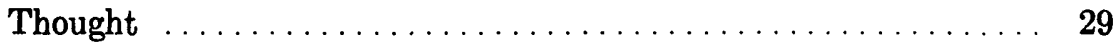

Henry L. Eaton: Cadasters and Censuses of Muscovy ........... 54

Roman Szporluk: Pokrovskii's View of the Russian Revolution ..... 70

Imre Boba: The Episcopacy of St. Methodius . . . . . . . . . . 85

Abraham Ascher: Axelrod and Kautsky .................. 94

NOTES AND COMMENTS

Robert V. Daniels: Soviet Historians Prepare for the Fiftieth ...... 113

REVIEW ARTICLES

George D. Jackson, Jr.: Toward a New Style in Surveys ......... 119

Ethel Dunn: Russian Sectarianism in New Soviet Marxist Scholar-

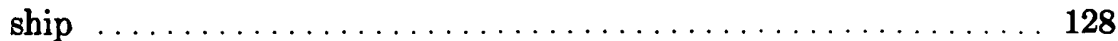

Ivan L. Rudnytsky: A Publication of the German Writings of Ivan Franko ................................ 141

Richard Hellie: The Foundations of Russian Capitalism ......... 148

LETTERS . . . . . . . . . . . . . . . . . . . . . . . . . . 155

NEWS OF THE PROFESSION $\ldots \ldots \ldots \ldots \ldots \ldots \ldots \ldots \ldots \ldots$

BOOKS RECEIVED $\ldots \ldots \ldots \ldots \ldots \ldots \ldots \ldots \ldots \ldots \ldots \ldots, \mathbf{1 6 7}$

INDEX TO VOLUME XV (1966) $\ldots \ldots \ldots \ldots \ldots \ldots \ldots \ldots \ldots .173$

\section{Number 2, June 1967}

\section{ARTICLES}

Bertram D. Wolfe: Backwardness and Industrialization in Russian History and Thought ....................... 177

Donald D. Egbert: Politics and the Arts in Communist Bulgaria . . . . 204 Rimvydas Silbajoris: Dynamic Elements in the Lyrics of Fet . . . . 217 
Stavro Skendi: Crypto-Christianity in the Balkan Area under the Ottomans ................................227

Robert D. Warth: On the Historiography of the Russian Revolution .. 247 David MacKenzie: Kaufman of Turkestan: An Assessment of His Administration (1867-1881) ...................... 265

\section{TRANSLATION}

Anthony D. Briggs: "Count Nulin" by Alexander Pushkin

REVIEW ARTICLE

René Wellek: New Czech Books on Literary History and Theory

FORUM

Paul Hollander: Observations on Bureaucracy, Totalitarianism, and the Comparative Study of Communism ................. 302

Konstanty Żantuan: Between Author and Reviewer ........... 308

REVIEWS ..................................... 315

LETTERS . . . . . . . . . . . . . . . . . . . . . . . . . 351

NEWS OF THE PROFESSION $\ldots \ldots \ldots \ldots \ldots \ldots \ldots \ldots \ldots .352$

BOOKS RECEIVED ........................... 356

\section{Number 3, September 1967}

ARTICLES

Marian Wenzel: The Dioscuri in the Balkans ............... 363

Grzegorz Leopold Seidler: Marxist Legal Thought in Poland ....... 382

Marc Raeff: Filling the Gap between Radishchev and the Decembrists .................................... 395

Abbott Gleason: The Emigration and Apostasy of Lev Tikhomirov . . 414 Andrzej Korbonski: The Polish Communist Party 1938-1942 . ..... 430

Franklin A. Walker: Constantine Pavlovich: An Appraisal ........ 445

Rex A. Wade: Argonauts of Peace: The Soviet Delegation to Western Europe in the Summer of $1917 \ldots \ldots \ldots \ldots \ldots \ldots \ldots \ldots .453$

NOTES AND COMMENTS

Joseph O. Baylen: Bishop Strossmayer and Mme. Olga Novikov: Two Unpublished Letters, $1879 \ldots \ldots \ldots \ldots \ldots \ldots \ldots \ldots \ldots \ldots .468$

Charles E. Timberlake: The Leningrad Collection of Zemstvo Publications

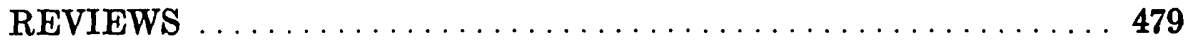

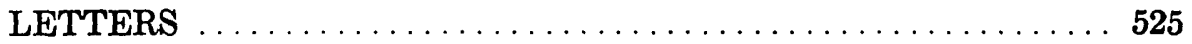

NEWS OF THE PROFESSION $\ldots \ldots \ldots \ldots \ldots \ldots \ldots \ldots \ldots .528$

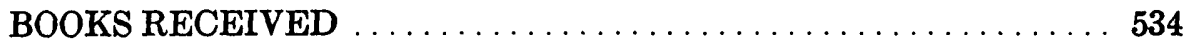

\section{Number 4, December 1967}

\section{DISCUSSION}

Ihor Sevčenko: Muscovy's Conquest of Kazan: Two Views Reconciled 
Edward Louis Keenan, Jr.: Muscovy and Kazan: Some Introductory Remarks on the Patterns of Steppe Diplomacy ........... 548

Jaroslaw Pelenski: Muscovite Imperial Claims to the Kazan Khanate . . 559

Omeljan Pritsak: Moscow, the Golden Horde, and the Kazan Khanate from a Polycultural Point of View ..................... 577

ARTICLES

Clarence Brown: Into the Heart of Darkness: Mandelstam's Ode to Stalin ................................... 584

Simon Karlinsky: Surrealism in Twentieth-Century Russian Poetry: Churilin, Zabolotskii, Poplavskii .................... 605

Lech Trzeciakowski: The Prussian State and the Catholic Church in Prussian Poland 1871-1914 ......................... 618

NOTES AND COMMENTS

Daniel R. Brower: The Problem of the Russian Intelligentsia ....... 638

Taras Hunczak: Polish Colonial Ambitions in the Inter-War Period . . 648

FORUM

David T. Cattell: A Neo-Marxist Theory of Comparative Analysis . . 657

Wiktor Weintraub: In Lieu of a Discussion ................663 663

Question of a September 1936 Plenum of the CPSU Central Committee ..................................6.665

Abdurakhman Avtorkhanov: A Few Questions concerning the Great Purge (An Answer to My Critics)

Comments by John A. Armstrong, Robert M. Slusser, and George F. Kennan

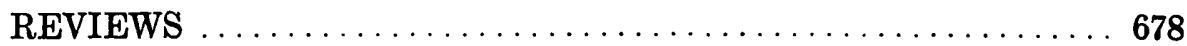

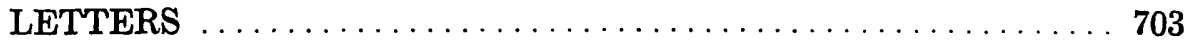

DOCTORAL DISSERTATIONS 1966-1967 (Compiled by Jesse J.

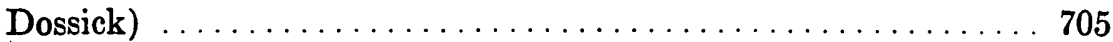

NEWS OF THE PROFESSION $\ldots \ldots \ldots \ldots \ldots \ldots \ldots \ldots \ldots \ldots$

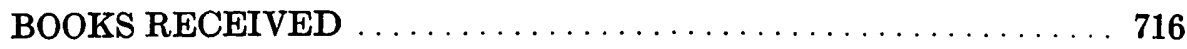

INDEX TO VOLUME XXVI (1967) $\ldots \ldots \ldots \ldots \ldots \ldots \ldots \ldots, 721$ 